\title{
Eksploitasi Sempadan Jurang Sebagai Usaha Pariwisata Di Desa Pecatu Kecamatan Kuta Selatan Kabupaten Badung
}

I Wayan Merta Yasa a, 1 I Nyoman Sunarta a2

1 mertayasa692@gmail.com, 2nyoman_sunarta@unud.ac.id

a Program Studi Sarjana Destinasi Pariwisata, Fakultas Pariwisata, Universitas Udayana, Jl. Dr. R. Goris, Denpasar, Bali 80232 Indonesia

\begin{abstract}
This research was carried out because there were problems regarding the exploitation of tourism business development in the cliff border area in Pecatu Village, South Kuta District, Badung Regency. Exploitation that occurs like tourism business development. The tourism business is like accommodation and restaurants. So researchers are interested in researching on the topic.

The research method used is qualitative analysis, with interview, observation and documentation techniques. Theories and concepts used are functional theories and concepts of exploitation, tourism policies, borderline cliffs and tourism businesses.

The results of the study show that there are 157 tourism business buildings in Pecatu Village, and some of them are recorded using cliff borders. As for the dominant tourism business using a cliff border, namely hotel and restaurant accommodation businesses. From the violation, the government of Pecatu Village and Badung Regency Government gave a policy in the form of awig-awig and written regulations to regulate these violations.

The conclusions in this study were the violation of tourism business development in Pecatu Village which uses a cliff border area. Massive businesses are being built in hotel and restaurant accommodation businesses. so that from this case the government of Pecatu Village and the Badung Regency Government issued a policy to regulate these violations so as not to occur again. Researchers suggest that they need to be given strict sanctions against offenders, or direct demolition by the Desa Adat, because the Desa Adat in Bali is feared by investors.
\end{abstract}

Keywords: exploitation, exploitation of cliff border, tourism policy

\section{PENDAHULUAN}

Pulau Bali adalah pulau tropis yang memiliki pesona alam yang menakjubkan, dan merupakan destinasi wisata unggulan di Indonesia. Sektor utama pendapatan Bali yaitu terletak pada sektor pariwisatanya, karena banyak wisatawan yang berlibur ke Bali untuk menikmati alam dan seni budaya Bali yang dikemas dalam sektor pariwisata itu sendiri.

Desa Pecatu merupakan salah satu desa yang berada di Bali, tepatnya di Kecamatan Kuta Selatan, Kabupaten Badung, yang telah mengembangkan sektor pariwisatanya. Desa Pecatu memiliki potensi alam berupa pantaipantai yang indah dan memiliki keunikannya tersendiri. Adapun pantai-pantai tersebut yaitu Pantai Dreamland, Pantai Bingin, Pantai Padang-Padang, Pantai Labuan Sait, Pantai Suluban dan Pantai Nyang-Nyang. Tidak hanya itu, Desa Pecatu juga memiliki satu ikon parwisata budaya yaitu Kawasan Luar Pura Uluwatu, dibalik fungsinya sebagai tempat peribadatan umat Hindu, Pura Uluwatu juga dikembangkan sebagai daya tarik wisata yang setiap harinya mampu mendatangkan banyak wisatawan.
Pesatnya pengembangan pariwisata di Desa Pecatu, sehingga membutuhkan usahausaha pariwisata untuk mendukung kebutuhan para wisatawan. Kebutuhan wisatawan tersebut seperti, akomodasi perhotelan dan makanan minuman (restoran), sehingga dari adanya usaha pariwisata pendukung tersebut, wisatawan dapat merasakan kenyamanan saat berwisata ke daya tarik wisata yang terdapat di Desa Pecatu.

Masifnya pembangunan usaha-usaha pariwisata di Desa Pecatu mengakibatkan kerusakan lingkungan karena terjadinya alih fungsi lahan. Usaha-usaha pariwisata yang dominan dibangun di Desa Pecatu yaitu akomodasi perhotelan dan jasa makanan dan minuman seperti restoran. Sehingga lahan kosong di Desa Pecatu semakin menipis dari adanya pembangunan-pembangunan tersebut.

Menipisnya lahan di Desa Pecatu, sehingga membuat investor melirik kawasan tebing/jurang di Desa Pecatu, karena jurangjurang yang terdapat di Desa Pecatu berbatasan langsung dengan pantai-pantai yang ada di Desa Pecatu, sehingga dari jurang-jurang tersebut dapat terlihat langsung pemandangan pantai yang indah serta dapat dilihat selama 24 jam. Kemudian dibangunlah usaha-usaha 
pariwisata di kawasan sempadan jurang tersebut karena memiliki nilai jual yang tinggi terhadap para wisatawan.

$\begin{array}{ccc}\text { Peraturan } & \text { yang } & \text { mengatur } \\ \text { pembangunan } & \text { usaha-usaha } & \text { pariwisata }\end{array}$
khususnya di Kabupaten Badung telah termuat dalam Peraturan Daerah Kabupaten Badung Nomor 26 Tahun 2013 tentang Rencana Tata Ruang Wilayah Kabupaten Badung Tahun 20132033, yang didalam peraturan tersebut menyatakan bahwa tidak boleh membangun pada area jurang atau sempadan jurang, akan tetapi pada realitanya pembangunanpembangunan usaha pariwista di sempadan jurang di Desa Pecatu terus terjadi. Pembangunan usaha pariwisata secara berlebihan atau mengeksploitasi kawasan sempadan jurang di Desa Pecatu tentunya akan berdampak buruk terhadap lingkungan atau alam disekitarnya. Sehingga perlu adanya kebijakan dan ketegasan dari pemerintah untuk menjaga dan melestarikan lingkungan khususnya kawasan sempadan jurang di Desa Pecatu.

Permasalahan yang terjadi tersebut, mengakibatkan peneliti menjadi tertarik untuk menjadikan topik ini sebagai judul penelitian, yaitu "Eksploitasi Sempadan Jurang sebagai Usaha Pariwisata di Desa Pecatu, Kecamatan Kuta Selatan, Kabupaten Badung", dimana peneliti akan menganalisis mengenai Bagaimana praktik eksploitasi sempadan jurang sebagai usaha pariwisata di Desa Pecatu dan menganalisis Bagaimana kebijakan pemerintah terhadap eksploitasi sempadan jurang di Desa Pecatu. Sehingga hasil penelitian ini diharapkan dapat memberikan sumbangan pemikiran terhadap pihak pemerintah dan stakeholder pariwisata agar dapat melaksanakan peraturan dengan baik, dan alam di Pecatu dapat terjaga kelestariannya.

\section{KEPUSTAKAAN}

\subsection{Tinjauan Penelitian sebelumnya}

Penelitian yang terkait focus penelitian yaitu penelitian yang dilakukan oleh Muliarsi, dkk tahun 2015, dengan judul "Penerapan Perda Tata Ruang Kabupaten Bangli terkait Ketentuan Sempadan Jurang di Sepanjang Jalan Raya Penelokan Kintamani", yang memiliki kesamaan yaitu mengenai kebijakan, serta memiliki perbedaan mengenai lokasi penelitian.

\subsection{Tinjaun Teori dan Konsep}

Penelitian ini menggunakan teori dan konsep-konsep diantaranya Teori Fungsional dari Malinowski dalam Pujani, dkk (2017), guna untuk menganalisis perubahan fungsi yang terjadi di Desa Pecatu, khusunya kawasan jurang yang di jadikan sebagai tempat berdirinya usaha-usaha pariwisata. Selanjutnya Konsep Kebijakan (Frederick dalam Nawawi, 2009), guna untuk menganalisis kebijakan yang berlaku untuk mengatur pembangunan kawasan sempadan jurang yang dikeluarkan oleh pemerintah. Selanjutnya Konsep Eksploitasi (Pasal 33 ayat 3 UUD Tahun 1945) guna untuk menganalisis eksploitasi yang terjadi khususnya bentuk eksploitasi kawasan sempadan jurang di Desa Pecatu.

\section{METODE PENELITIAN}

Sumber data yang digunakan dalam penelitian ini terdiri dari data primer dan data sekunder, adapun data primernya yaitu data yang didapatkan langsung dari pengamatan peneliti mengenai praktik eksploitasi sempadan jurang sebagai akomodasi pariwisata dan kebijakan pemerintah terhadap eksploitasi sempadan jurang sebagai akomodasi pariwisata di Desa Pecatu, sedangkan data sekundernya adalah profil Desa Pecatu dan data usaha pariwisata di Desa Pecatu.

Pengumpulan data dilakukan dengan melakukan observasi, wawancara dan studi kepustakaan. Observasi saat penelitian ini untuk mengamati secara langsung gambaran umum serta praktik eksploitasi sempadan jurang sebagai usaha pariwisata dan kebijakan pemerintah terhadap eksploitasi sempadan jurang sebagai usaha pariwisata di Desa Pecatu salain itu dilakukan wawancara indepth interview guna untuk mendapatkan informasi yang lebih mendalam mengenai fokus penelitiaan yaitu praktik eksploitasi sempadan jurang sebagai usaha pariwisata dan kebijakan pemerintah terhadap eksploitasi sempadan jurang sebagai usaha pariwisata di Desa Pecatu. Serta dilakukan studi kepustakaan dalam menambah wawasan peneliti terkait usaha pariwisata dan kebijakan pemerintah terhadap eksploitasi sempadan jurang sebagai usaha pariwisata di Desa Pecatu.

Analisis data dalam penelitian ini yaitu analisis kualitatif (Sugiyono, 2014), kemudian dengan melaksanakan tahapan-tahapan seperti 
pengumpulan data, reduksi data, penyajian data, dan verifikasi.

\section{HASIL DAN PEMBAHASAN \\ 4.1 Gambaran Umum Desa Pecatu}

Desa Adat Pecatu terletak diujung selatan Pulau Bali yang lebih tepatnya pada Kecamatan Kuta Selatan, Kabupaten Badung yang wilayahnya cukup luas mencapai $2.685,17$ Ha dan memiliki jumlah penduduk yang besar sekitar 7900 jiwa. Ketinggian tanah Desa Pecatu yaitu 175 meter dari permukaan air laut. Secara geografis Desa Pecatu memiliki batas-batas wilayah adalah sebagai berikut:

1. Sebelah Utara : Kelurahan Jimbaran

2. Sebelah Selatan: Samudra Indonesia

3. Sebelah Timur : Tukad Gau, Desa Ungasan

4. Sebelah Barat : Samudra Indonesia

Desa Adat Pecatu terdiri atas tiga banjar yakni Banjar Kangin, Banjar Tengah dan Banjar Kauh dan di masing-masing banjar tersebut terdiri 9 banjar dinas dan 19 tempekan.

Desa Pecatu memiliki kawasan sempadan jurang yang berbatasan langsung dengan pantai-pantai yang berada di Desa Pecatu, kemudian pada kawasan tersebut telah didirikan usaha-usaha pariwisata, adapun kawasan sempadan jurang dapat dijelaskan dalam Gambar 1 Peta Batasan Desa Pecatu, dimana garis garis titik-titik kuning merupakan kawasan sempadan jurang sedangkan garis merah merupakan batas Desa Pecatu.

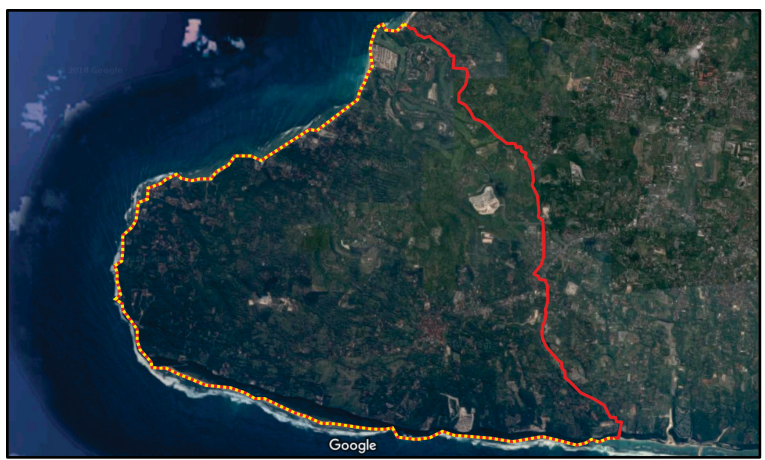

Gambar 1 Peta Batasan Desa Pecatu

Sumber: Modifikasi Peneliti, 2018

\subsection{Potensi Desa Pecatu}

Potensi wisata di Desa Pecatu dapat dibagi menjadi dua yaitu potensi alam dan potensi budaya. Dari adanya potensi tersebut maka dikembangkan menjadi daya tarik wisata di Desa Pecatu, dan pembangunan usaha pariwisata pula mengikutinya guna untuk memenuhi kebutuhan dari wisatawan Selanjutnya akan dijelaskan potensi alam dan potensi budaya di Desa Pecatu yaitu sebagai berikut.

\subsubsection{Potensi Alam}

Potensi alam Desa Pecatu terletak pada pantai diantaranya yaitu Pantai Dreamland, Pantai Bingin, Pantai Padang-Padang, Pantai Labuan Sait, Pantai Suluban dan Pantai NyangNyang yang dimana terdapat jurang atau tebing yang mengelilingi panti-pantai tersebut yang kini beberapa telah didirikan berbagai usaha pariwisata karena memiliki view yang langsung memandang ke pantai sehingga memiliki nilai jual yang tinggi.

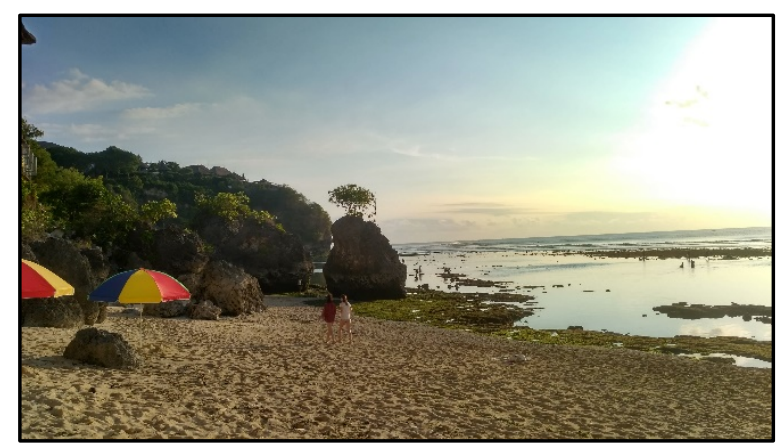

Gambar 2 Pantai Bingin

Sumber: Dokumentasi Peneliti, 2019

\subsubsection{Potensi Budaya}

Potensi budaya yang yang terkenal dan telah menjadi ikon pariwisata di Desa Pecatu yaitu Kawasan Luar Pura Uluwatu, dibalik fungsinya sebagai tempat peribadatan umat Hindu, Pura Uluwatu juga berkembang sebagai daya tarik wisata yang mendatangkan banyak wisatawan disetiap harinya. Selain itu wisatawan juga dapat menyaksikan sunset di sore hari beserta menyaksikan tari-tari Bali seperti Tari Kecak dan lainnya. Pura Uluwatu memberikan dampak positif terhadap lingkungan disekitarnya serta kawasan sempadan jurang dapat terjaga sejauh 5.000 meter sehingga dapat steril dari pembangunan. 


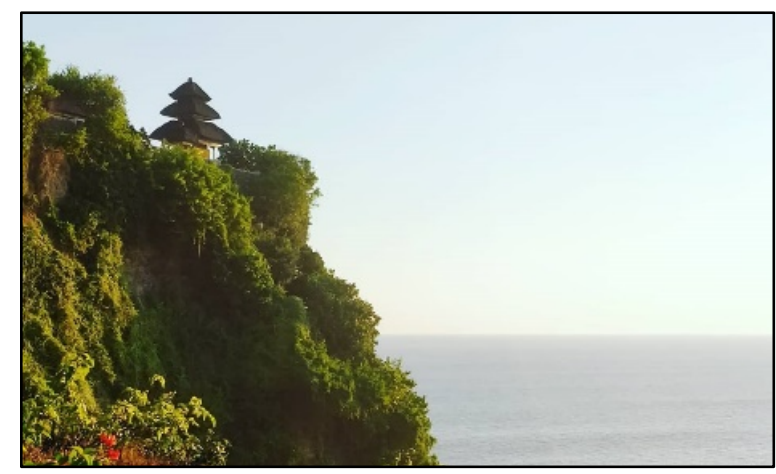

Gambar 3 Pura Uluwatu

Sumber: Pokdarwis Desa Pecatu, 2017

\subsection{Praktik Eksploitasi Sempadan Jurang sebagai Usaha Pariwisata di Desa Pecatu}

Desa Pecatu memiliki potensi yang luar biasa untuk dikembangkan sebagai daya tarik wisata unggulan di Bali, karena memiliki potensi alam berupa pantai-pantai yang indah dengan keunikannya masing-masing, serta Desa Pecatu juga memiliki potensi budaya yang telah terkenal yaitu Kawasan luar Pura Uluwatu, yang terus mendatangkan banyak wisatawan.

Untuk menunjang kegiatan pariwisata di Desa Pecatu maka dibutuhkanlah usahausaha pariwisata agar kebutuhan wisatawan dapat terpenuhi. Melihat peluang tersebut, masyarakat lokal dan investor mulai memanfaatkan kesempatan yang bagus ini untuk menyediakan usaha pariwisata guna untuk menunjang kebutuhan wisatawan yang datang ke Desa Pecatu baik dalam penyedia akomodasi perhotelan maupun tempat makan dan minum atau restoran, sehingga akan berdampak pula bagi peningkatan perekonomian masyarakat lokal maupun investor tersebut. Akan tetapi dibalik maraknya pembangunan tersebut ada beberapa bangunan yang melanggar aturan yang berlaku.

Sampai saat ini, lahan-lahan di Desa Pecatu sudah didirikan usaha pariwisata seperti, berbagai jenis akomodasi seperti hotel, villa, penginapan dan berbagai usaha makanan dan minuman yang terdata sampai saat ini sejumlah 157 bangunan (Data Usaha Pariwisata di Desa Pecatu Tahun, 2018). Dari banyaknya bangunan usaha pariwisata tersebut, terdata banyak yang melakukan pelanggaran terutama melanggar pembangunan pada kawasan sempadan jurang.

Sempadan jurang memiliki nilai jual yang tinggi dibandingkan dengan lahan lainnya yang berada di Desa Pecatu, karena dari sempadan jurang wisatawan dapat menyaksikan view yang abadi (pantai-pantai di Desa Pecatu) selama 24 jam. Itulah yang menyebabkan para investor membanguan usaha pariwisata pada sempadan jurang di Desa Pecatu agar memperoleh estetika yang baik dan membuat nilai jual yang tinggi terhadap customer atau wisatawan yang menggunakan dan mengakses usaha pariwisata tersebut.

Masifnya pembangunan-pembangunan usaha pariwisata di Desa Pecatu, khususnya yang memanfaatkan area sempadan jurang dapat dirasakan bahwa terjadi praktik eksploitasi sumber daya alam berupa pengkerukan jurang dan pendangkalan jurang untuk pembangunan usaha pariwisata yang begitu banyaknya di Desa Pecatu yang dilakukan oleh investor usaha pariwisata, sehingga dari terjadinya praktik eksploitasi tersebut, menimbulkan dampak negatif terhadap lingkungan dimana terjadinya alih fungsi lahan yang merusak ekosistem lingkungan serta mengurangi lahan hijau di Desa Pecatu.

\subsection{Kebijakan Pemerintah dalam Melestarikan Sempadan Jurang Desa Pecatu}

Pemerintah yang dimaksud dalam penelitian ini yaitu pemerintah yang memberikan kebijakan untuk melestarikan sempadan jurang di Desa Pecatu diantaranya ada Pemerintah Daerah Kabupaten Badung, Pemerintah Desa Pecatu serta akan ditambahkan pula kebijakan dari pengusaha pariwisata yang memiliki bangunan akomodasi dan restoran di Desa Pecatu. Dimana ketiga elemen tersebut memiliki peranan penting untuk melestarikan dan menjaga sempadan tebing di Desa Pecatu agar dapat berkelanjutan.

\subsubsection{Kebijakan Pemerintah Daerah Kabupaten Badung dalam Melestarikan Sempadan Jurang Desa Pecatu \\ Upaya Pemerintah Daerah Kabupaten} Badung untuk melestarikan kawasan sempadan jurang yaitu dengan mengeluarkan Peraturan Daerah Kabupaten Badung Nomor 26 Tahun 2013 tentang Rencana Tata Ruang Wilayah Kabupaten Badung Tahun 2013 sampai 2033. Dimana dijelaskan bahwa kawasan sempadan jurang dalam Pasal 25 huruf c \& d, yang 
berbunyi (c) Lembah-lembah bukit di Wilayah Kecamatan Petang dan Kecamatan Kuta Selatan; dan (d) Tebing-tebing di seluruh Wilayah Kabupaten Badung.

Pembangunan pada sempadan jurang harus mengikuti ketentuan umum Peraturan Zonasi Kawasan Sempadan Jurang (ZKSJ) sebagaimana dimaksud dalam Pasal 69 ayat (2) meliputi huruf a, b, g yang berbunyi (a)Daratan di tepian jurang yang memiliki kemiringan lereng sekurang-kurangnya 45\%, kedalaman sekurang-kurangnya lima meter dan bidang datar bagian atas sekurang-kurangnya sebelas meter; (b)Sempadan Jurang bagian atas sebagaimana dimaksud pada huruf (a),harus memiliki lebar sekurang-kurangnya dua kali kedalaman jurang dan tidak kurang dari sebelas meter dihitung dari tepi jurang ke arah bidang datar; (g)Sempadan Jurang dapat kurang dari ketentuan pada huruf (b) untuk bangunbangunan yang berada di Wilayah Kecamatan Kuta Selatan setelah dinyatakan stabil melalui penelitian teknis dari instansi berwenang, dengan ketentuan tidak kurang dari sebelas meter dari tepi jurang. Kemudian apabila ada usaha pariwisata yang berada dalam kawasan sempadan jurang tersebut, dapat dikategorikan termasuk dalam zonasi pelanggaran kawasan sempadan jurang serta mendapat sanksi sanksi administratif diatur pada Pasal 112 dan dapat dijatuhkan sanksi pidana yang diatur dalam Pasal 115 Ayat 1 guna untuk menertibkan pembangunan liar dan pembangunan yang menyalahi aturan di Kabupaten Badung. Pemerintah Daerah Kabupaten Badung memiliki peran dalam penataan ruang yaitu dalam pengaturan, pembinaan, pengawasan, terhadap pelaksanaan penataan ruang di wilayah kabupaten dan kawasan strategis kabupaten agar pembangunan sesuai peraturan dan tidak adanya pelanggaran lagi.

Berdasarkan atas kebijakan yang

dikeluarkan oleh Pemerintah Daerah Kabupaten Badung yaitu Peraturan Daerah Kabupaten Badung Nomor 26 Tahun 2013 tentang Rencana Tata Ruang Wilayah Kabupaten Badung Tahun 2013 sampai 2033, maka dapat diketahui bahwa terdapat 12 usaha pariwisata berjenis akomodasi perhotelan, villa, resort dan restoran yang terdata melanggar sempadan jurang di Desa Pecatu diantaranya yaitu El Kabron Restaurant \& Cliff Bar, The Sterling Hotel \& Villa, Usaha Jasa Wisata di
Pantai Bingin, Villa Bayuh Sabha, C151 Luxury Villas Dreamland, Anantara Uluwatu Bali Resort, Suarga Padang-Padang, Villa Laut Bali, Suluban Cliff Bali Villa, Ulu Cliff House, Single Fin Bali dan Villa Anugrah (Data Usaha Pariwisata yang terdata oleh peneliti, 2018). Usaha pariwisata tersebut memanfaatkan lahan sempadan jurang untuk tempat pembangunan bahkan mirisnya melakukan eksploitasi lingkungan berupa pengkerukan jurang dan pendangkalan jurang, agar mendapatkan bidang datar untuk pembangunannya, sehingga estetika bentuk gedung dan view pantai yang dicari oleh investor tersebut, terlihat semakin bagus.

Usaha-usaha pariwisata yang melanggar kawasan sempadan jurang di Desa Pecatu akan ditampilkan dalam beberapa gambar yaitu dalam Gambar 4 El Kabron Restaurant \& Cliff Bar, Gambar 5 Anantara Uluwatu Bali Resort, Gambar 6 Ulu Cliff House, yaitu sebagai berikut.

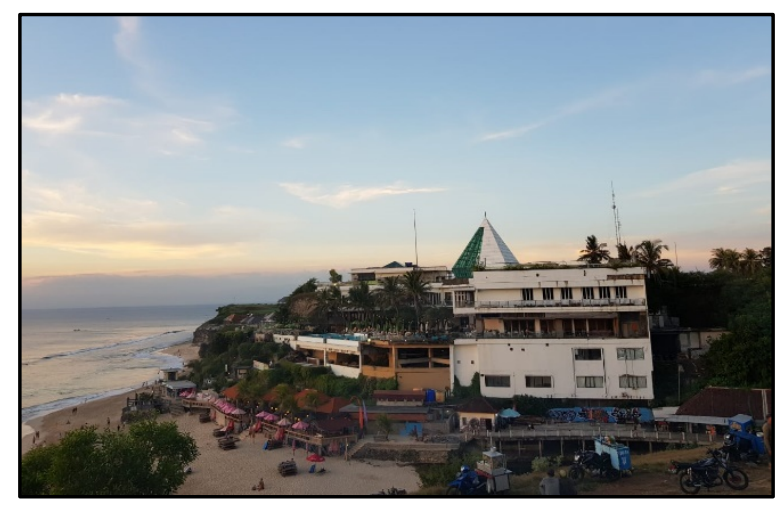

Gambar 4 El Kabron Restaurant \& Cliff Bar Sumber: Dokumentasi Peneliti, 2019

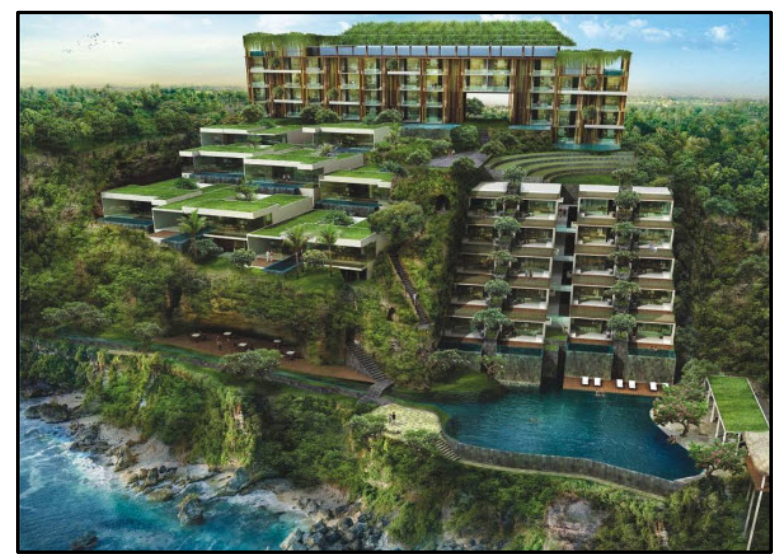

Gambar 5 Anantara Uluwatu Bali Resort Sumber: Instagram Anantara Uluwatu, 2018 


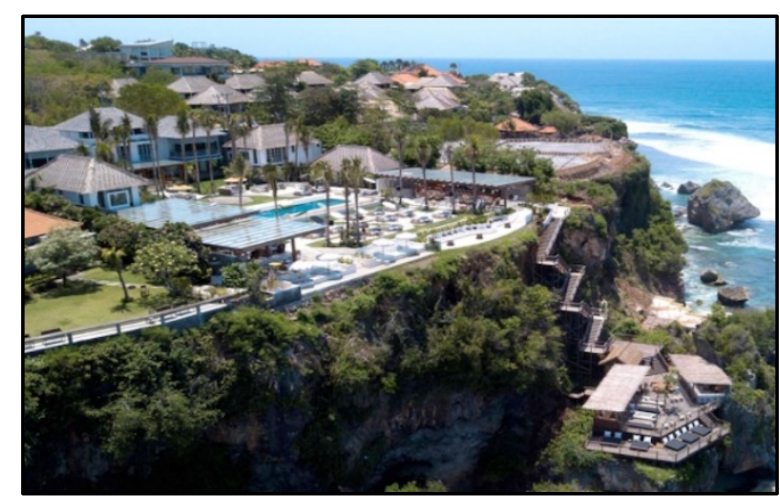

Gambar 6 Ulu Cliff House

Sumber: Instagram Ulucliffhouse, 2018

Gambar 4, Gambar 5 dan Gambar 6 merupakan usaha pariwisata berupa akomodasi perhotelan dan restoran yang berada di Desa Pecatu, dan telah memiliki izin pembangunan, akan tetapi pelanggaran yang terdata dari usaha pariwisata tersebut terletak pada pembangunan infrastruktur seperti jalan, kolam renang, jembatan pada tebing serta bangunan pendukung untuk menikmati view.

\subsubsection{Kebijakan Pemerintah Desa Pecatu dalam Melestarikan Sempadan Jurang Desa Pecatu}

Pemerintah Desa Pecatu dalam upaya untuk melestarikan kawasan sempadan jurang di Desa Pecatu telah melakukan prosedur sesuai peraturan dari pusat yaitu Perda Kabupaten Badung No 26 Tahun 2013 tentang RTRW Kabupaten Badung Tahun 2013-2033 serta berpatokan dengan awig-awig Desa Pecatu dalam memproses izin pembangunan serta menerapkan peraturan tersebut kepada para pembangun di Desa Pecatu. Selain itu Pemerintah Desa Pecatu rutin melaksanakan Paum Desa atau musyawarah desa setiap 6 bulan sekali, dimana dalam musyawarah tersebut menjelaskan kepada para masyarakat yang hendak membangun usaha pariwisata agara berpatokan terhadap peraturan yang berlaku seperti tidak membangun pada zonasi kawasan suci serta tidak membangun pada kawasan sempadan jurang dan bentuk bangunannyapun harus berpatokan terhadap peraturan yang berlaku. Pemerintah Desa Pecatu juga melakukan sosialisasi aturan pembangunan dan penandatanganan $M O U$ terhadap pihak investor agar tidak terjadinya pelanggaran peraturan yang berlaku.
Kebijakan tersebut dilakukan dalam upaya untuk menertibkan RTRW serta untuk kedepannya agar tidak ada yang melanggar aturan khususnya RTRW lagi dan lahan di Desa Pecatu dapat terjaga khususnya pada sempadan jurang, dan apabila terdapat pembangunan usaha pariwisata tentunya diharapkan untuk mengikuti aturan-atura maupun awig-awig yang berlaku di Desa Pecatu, agar terciptanya kelestarian lingkungan.

\subsubsection{Kebijakan Pengusaha Pariwisata}

Peran stakeholder pariwisata khususnya investor menjadi sangat penting dalam menjaga kelestarian alam di Pecatu, karena investorlah yang dapat membangun usaha-usaha pariwisata di Desa Pecatu. Para investor juga harus dapat mengikuti peraturan yang berlaku demi kenyamanan dan keamaanan yang berada di Desa Pecatu dan Kabupaten Badung.

Setiap pengusaha pariwisata harus dapat menjaga dan menghormati norma agama, adat istiadat, budaya dan nilai-nilai yang hidup dalam masyarakat setempat, memelihara kelestarian lingkungan alam dan budaya serta menerapkan standar usaha yang diterapkan oleh peraturan perundang-undangan.

Dari ketiga aspek tersebut, antara Pemerintah Daerah Kabupaten Badung, Pemerintah Desa Pecatu, Pengusaha pariwisata serta masyarakat diharapkan mampu menjalin hubungan yang baik, serta menjalankan peraturan yang berlaku sehingga terjadinya kenyamanan dan tidak memunculkan konflik. Maka dari itu kelestarian lingkungan di Desa Pecatu dan kawasan jurangnya dapat terjaga kelestariannya.

\section{PENUTUP}

\subsection{Kesimpulan}

1. Praktik Eksploitasi Sempadan Jurang sebagai Usaha Pariwisata di Desa Pecatu

Kawasan sempadan jurang di Desa Pecatu pun sangat digemari untuk pembangunan karena memiliki kelebihan yaitu memiliki nilai keunikan yang dapat menjadi ciri khas dibandingkan bangunan yang didirikan di lahan yang biasa, karena pada sempadan jurang, wisatawan dapat melihat view pantai atau lautan secara langsung selama 24 jam. Akan tetapi bangunan yang didirikan di sempadan jurang memiliki resiko yang cukup tinggi 
salah satunya terjadi kelongsoran, selain itu masifnya pembangunan-pembangunan usaha pariwisata di Desa Pecatu, khususnya yang memanfaatkan area sempadan jurang dapat dirasakan bahwa terjadi praktik eksploitasi sumber daya alam berupa pengkerukan jurang dan pendangkalan jurang untuk pembangunan usaha pariwisata yang begitu banyaknya di Desa Pecatu yang dilakukan oleh investor usaha pariwisata, sehingga dari terjadinya praktik eksploitasi tersebut, menimbulkan dampak negatif terhadap lingkungan dimana terjadinya alih fungsi lahan yang merusak ekosistem lingkungan serta mengurangi lahan hijau di Desa Pecatu.

2. Kebijakan Pemerintah dalam Melestarikan Sempadan Jurang Desa Pecatu

Peraturan-peraturan mengenai pembangunan dan pelanggaran telah diaplikasikan oleh Pemerintah Daerah Kabupaten Badung yaitu Peraturan Daerah Kabupaten Badung Nomor 26 Tahun 2013 tentang Rencana Tata Ruang dan Wilayah Kabupaten Badung Tahun 2013-2033 yang berisikan peraturan mengenai khususnya pembangunan pada kawasan sempadan jurang dan sanksi hukum yang dikenakan kepada para pelanggar, sehingga dari berlakunya peraturan tersebut terdata terdapat 12 usaha pariwisata berjenis akomodasi perhotelan, villa, resort dan restoran yang terdata melanggar sempadan jurang di Desa Pecatu diantaranya yaitu $E l$ Kabron Restaurant \& Cliff Bar, The Sterling Hotel \& Villa, Usaha Jasa Wisata di Pantai Bingin, Villa Bayuh Sabha, C151 Luxury Villas Dreamland, Anantara Uluwatu Bali Resort, Suarga Padang-Padang, Villa Laut Bali, Suluban Cliff Bali Villa, Ulu Cliff House, Single Fin Bali dan Villa Anugrah (Data Usaha Pariwisata yang terdata oleh peneliti, 2018). Pemerintah Desa Pecatu juga telah melakukan prosedur yang benar sesuai peraturan dan awig-awig yang berlaku untuk mengatur pembangunan, serta diharapkan para stakeholeder pariwisata dapat melaksanakan peraturan tersebut sehingga alam di Desa Pecatu dapat terjaga kelestarianya khusunya pada kawasan sempadan jurang.

\subsection{Saran}

1. Pemerintah Daerah Kabupaten Badung.

Peneliti berharap kepada Pemerintah Daerah Kabupaten Badung agar dapat melakukan tindakan tegas terhadap para pelanggar agar kasus serupa tidak terulang kembali dan memberikan sanksi yang tegas terhadap para pelanggar serta melakukan sosialisasi tentang peraturan dan melakukan cek lapangan untuk menghindari kecurangan dari investor.

2. Pemerintah Desa Pecatu

Peneliti berharap kepada Pemerintah Desa Pecatu agar menjaga kawasankawasan hijau di Desa Pecatu, serta menghimbau dan mensosialisasikan terhadap pengusaha pariwisata, investor, masyarakat Desa Pecatu agar mentaati peraturan yang sudah ada, guna untuk menjaga kelestarian Desa Pecatu khususnya kawasan sempadan jurang.

3. Pengusaha Pariwisata atau Investor

Peneliti berharap kepada pengusaha pariwisata maupun investor agar dapat mematuhi peraturan yang sudah ditetapkan oleh Pemerintah Daerah Kabupaten Badung dan Desa Pecatu agar terciptanya keselarasan lingkungan, sosial, budaya dan ekonomi.

4. Masyarakat Desa Pecatu

Peneliti berharap kepada masyarakat Desa Pecatu agar ikut berpartisipasi menjaga kawasan yang memang selayaknya tidak boleh di bangun dan masyarakat juga diharapkan untuk tidak menjual lahan khususnya sempadan jurang, serta masyarakat Desa Pecatu juga diharapkan agar mematuhi peraturan yang sudah ditetapkan oleh Pemerintah Daerah Kabupaten Badung dan Desa Pecatu Pecatu.

\section{DAFTAR PUSTAKA}

Desa Pecatu. 2017. "Profil Perkembangan Desa Pecatu Tahun 2017". Desa Pecatu

Desa Pecatu. 2018. "Data Usaha Pariwisata di Desa Pecatu Tahun 2018". Desa Pecatu

Desa Pecatu. 2018. "Profil Potensi Desa Pecatu Tahun 2018". Desa Pecatu.

Giri, Antoni. 2016. "Penegakan Hukum terhadap Pembangunan Hotel pada Kawasan Sempadan Jurang di Kabupaten Badung". Tugas Akhir Fakultas Hukum Universitas 
Vol. 7 No 1, 2019

Muliarsi, Trisniari. 2015. "Penerapan Perda Tata Ruang Kabupaten Bangli terkait Ketentuan Sempadan Jurang di Sepanjang Jalan Raya Penelokan Kintamani". Tugas Akhir Fakultas Hukum Universitas Udayana

Pemerintah Indonesia. 2007. “Undang-Undang Republik Indonesia Nomor 26 Tahun 2007 Tentang Penataan Ruang". Sekretariat Negara: Jakarta

Pemerintah Bali. 2009. "Peraturan Daerah Provinsi Bali Nomor 16 Tahun 2009 Tentang Rencana Tata Ruang Wilayah Provinsi Bali Tahun 2009 - 2029". Denpasar Bali

Pemerintah Indonesia. 2009. "Undang-Undang Republik Indonesia Nomor 10 Tahun 2009 Tentang Kepariwisataan". Sekretariat Negara: Jakarta

Pemerintah Kabupaten Badung. 2013. "Peraturan Daerah Kabupaten Badung Nomor 26 Tahun 2013 tentang Rencana Tata Ruang dan Wilayah Kabupaten Badung Tahun 2013-2033". Denpasar Bali

Pujani, Luh Putu Kerti dkk. 2017. "Eksploitasi Goa Pindul sebagai Speleo Tourism di Gunungkidul, Yogyakarta". Denpasar: Universitas Udayana. 